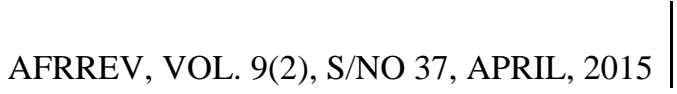 \\ African Research Review
}

An International Multidisciplinary Journal, Ethiopia

Vol. 9(2), Serial No. 37, April, 2015:24-40

ISSN 1994-9057 (Print) ISSN 2070-0083 (Online)

DOI: http://dx.doi.org/10.4314/afrrev.v9i2.3

\section{Poverty and Cultism in Our Contemporary Society: Implications for Nigerian Students}

\author{
Nnajieto, Charles C. \\ Department of Educational Foundations \\ Alvan Ikoku Federal College of Education, Owerri \\ Imo State, Nigeria \\ Email: drcharlesnnajieto@yahoo.com \\ Phone: +2348037069765 \\ \&
}

\author{
Ahamefula, Ernest I. \\ Department of Social Studies \\ Alvan Ikoku Federal College of Education, Owerri \\ Imo State, Nigeria \\ Phone: +2348035828364
}

\begin{abstract}
This paper is aimed at making an overview of the concepts of poverty and cultism in our contemporary society. The origin, causes, prevalent patterns, the implications on Nigerian students and the challenges posed by these concepts in our society were all $\mathrm{x}$-rayed. Whereas proper and adequate funding of public schools by both the Federal and State governments, advancement of international grants and aids, promotion of "pro-poor" policies i.e., Policies that focus on the welfare of the poor masses, good governance and to increase the performance and employment rate of Micro-Small and
\end{abstract}


Medium Enterprises (MSMEs) among others were identified as measures to be adopted for curbing poverty in the Nigerian society, some techniques found to be effective strategies for combating cultism in the society also include: coercion, persuasion, mass mobilisation campaign, public renunciation among others. The author concludes that the target of the government and stakeholders in education to eradicate cultism and poverty in our society would be achieved if only the successive government do not jettison their predecessors' agenda in line with the programme, rather incorporate theirs and allow both to run concurrently in order to reach their target audience.

\section{Introduction}

Poverty and cultism are serious challenges to all government in Nigeria. Poverty is a situation or experience of being poor. Poverty humiliates and dehumanises its victims. As Ukpong (1996) rightly noted:...poverty has earned recognition in the existence of its ravaging society and the affair of humanity at the international, national and local levels...the need exists now for urgent actions towards its eradication and control... indeed poverty is a snare. It is dehumanising... it must be eradicated (p.6).

Poverty itself is as old as the whole world. One of the Holy Scriptures even stated that "the poor shall never seize in your midst". this end, government and people in authority always strive to ensure that adequate structural programmes are enshrined to see that poverty if not eradicated, is reduced to the barest minimum. Some of these basic determinants of wellbeing include adequate food, shelter, portable water, healthcare, education and employment opportunities (Akunfola and Yusuf, 2001). Poverty and cultism are in fact heavy burden in the society.

Cultism on the other hand is a social vice because it is the most teething problem facing tertiary institutions in Nigeria. The Oxford Concise Dictionary of Sociology (1996) gives the sociological definition of cult as a small group or religious activities whose beliefs are typically secret, esoteric and individualistic. The Lexicon Webster's Dictionary defines secret cult as a group of people who share a common cause and whose mode of meetings and agenda are unknown to the public and where initiation into ranks and files is usually done in secret. Ogunbameru (2004) defines cultism or secret cult as any form of organisation whose activities are not exclusively kept away from the knowledge of others but such activities are carried out not at odd hours of the day and they often clash with the accepted norms and values of everyday life. The Oxford Advance Learners' Dictionary defines cultism as a system of religious worship especially one that is expressed in rituals. In a nutshell, cultism can be defined as a ritual practise by a group of people whose membership, admission, policy and initiation formalities as well as their mode of operations are kept secret with their activities having negative effects on both members and non-members alike. 
The origin of cult activities in Nigeria's higher institutions dates back to 1952 when Wole Soyinka and six others formed PYRATES CONFRATERNITY. The remaining six are Olumuyiwa Awe, Ralph Opara, Tunji Tubi, Diag Imokhuede, Pius Olegbe and Olu Agunloya. The basic objective of the confraternity at that time was to elevate the social life of the university campus where orderliness and discipline could be planted in the mind of youths who were expected to be future leaders in Nigeria. Adejoro (1995) lamented that little did Soyinka and his friends realised that they were making history, nor did they come to term with the fact that students and indeed youths radicalism was being given a national boost and the unleashing of a national vanguard. The development was paradoxical to the extent that they least realised that they were laying the foundation for what was to be transformed eventually into gansterism in educational institutions in Nigeria and the society at large.

Society is a particular large group of people who share laws, organisations and customs. It is also people in general, consider in relation to the laws, organisations, etc. that make it possible for them to live together. In the context of things of this paper, we are referring to the Nigerian Society.

The government and people have tried to eradicate the perennial problems and obstacles caused by poverty and cultism in the Nigerian contemporary society but all to no avail rather than decreasing the reverse becomes the case. Therefore, this paper is set to investigate the causes, effects and prevalent patterns of poverty and cultism and proffer suggestions on how toremediate the menace of poverty and cultism.

\section{Issues on Poverty and Cultism}

The cause of this state of poverty in Nigeria may be traced to the under-listed, among other factors: Corruption, bad governance, accumulated debt, unemployment, low productivity, population explosion, globalisation, unfocused government policies and lack of effective skills acquisition / training. In a bid to overcome poverty in Nigeria, the government has initiated different policies and structural programmes between 1977 till date.

There are numerous factors responsible for the poverty incidence. The causes are ubiquitous and in the psyche of the ruled and the rulers. While the ruled struggle to escape the poverty circle, the rulers are conscious of sliding back to experience poverty; thereby promoting corruption, misrule, injustice and other social vices. These scenarios notwithstanding, government of any affected nation must be seen as making conscious efforts to address the problems of poverty. This attempt though maybe taunted with deceit and or insincerity of purpose, nevertheless, it deserves an assessment of research for policy recommendation purposes. 
There are reasons why poverty has persisted in Nigeria and they include: poor macro-economic and monetary policies which have contributed to high poverty rate. The Nigerian naira that used to exchange for 1.20 naira to one British pound in 1986, now exchanges for more than $200 \%$ of what it was. The outcome has made it almost impossible for small and medium enterprises (SMEs) to thrive, which would have contributed to the reduction of poverty through job creation.

Secondly, globalisation is another factor that is contributing to high rate of poverty in Nigeria, by globalisation there is trade liberalisation. Nations are supposed to trade freely amongst themselves for the mutual benefits of their people. As for Nigeria, there are only two major goods that could be marketed -crude oil and agricultural produce. The latter is totally neglected with the discovery of the former in a commercial quantity. The gains of globalisation as currently being enjoyed by developed nations seem to be eluding Nigeria because of her inability to export manufactured goods abroad like other developed nations.

Nigeria is yet to experience good governance and this has deprived her people dividends of democracy. So lack of good governance is a determinant factor of poverty in Nigeria. Policies of governments are still being formulated without due consideration to the welfare of citizens, the outcome of which is further poverty.

Corruption and low productivity capacity are serious challenges in Nigeria. Money that accrued to governments at all levels are stolen and kept in private bank accounts at home and abroad by public officials. No meaningful investments, which would have generated employment for the people could take place in an environment plagued with corrupt practices. Industries that would have provided job opportunities for the people are either folding-up or producing at very low capacity, as a result unemployment is bound to increase.

Despite the fact that all manners of evil (such as examination malpractice, rape, robbery, arson, maiming, murder, killing, intimidation of fellow students and lecturers for good grades, love (girlfriend/boyfriend), clashes of rival cult group, among others) has become the prevalent pattern of cultism, some students of tertiary institutions still find it fashionable to engage in it for different reasons. Ogidefa (2008), an educationist, in the article entitled 'Cultism in Educational Institutions in Nigeria causes possible solutions and counselling implications', identified some reasons why students join cults. According to the source, search for responsibility, search for satisfaction of one's aspirations and needs, search for security and search for social identity are some of the reasons that can be explained below.

Search for responsibility: Some students join cult groups in order to perform certain services for the members. For instance, some students may engage in cultism in order to fight for perceived injustice in their campuses against their members. 
Search for Satisfaction of One's Aspiration and Needs: Some students also engage in cultism in order to satisfy their desire, aspirations and needs. Example of this is that a student may belong to a cult group which part of her objective is to ensure the success of her members in academic examinations.

Search for Security: Many students of tertiary institutions, especially the female students join secret cult in order to protect themselves while some male students join to secure their girlfriends.

Search for Social Identity: There are also students who join cult group for popularity. They want to make name and to be regarded as powerful people. For these students, to belong to a cult group is a way of achieving prestige and greatness. They believe that they could influence decisions on campus and that they could as well dictate the pace during the students' union and students representative elections.

Oshodomo (2009) commenting on the above article by Ogidela (2008), stated that some students join campus cult to gain respect and recognition and to acquire protection against sanctions from members of the community. He also added that students join cult groups for reasons based on past negative experiences at the family levels. There are others who join because they want to create avenues to exhibit and diffuse frustrations from the family, schools and society. There are students who join cult group for reason of wealth (financial assistance) why others join just to hide their weaknesses (inferiority complex) academic or social. Some are forced to join while others feel that the objectives of the cults are laudable and worthwhile. Other reasons while students engage in cultism might be influenced by parental and home background, because parents who are members of secret cults may not see anything wrong in their children's involvement in cultism. Students who are emotionally sick and possessed by the demons join cult groups to unleash terror on the society that has caused emotional distress thereby becoming criminals because of the evil spirit in them. Some students also become cultists because their friends are members. Some students join cult because certain lecturers and administrators are members of secret cults. Un-conducive learning facilities / environment and inadequate welfare programmes for students can also encourage students to engage in cultism.

Thompson (1998) pointed out that, the youths join cult because it provides members with security, it gives them licence to do anything and get away with it and finally to seek vengeance, Aboribo (1999) maintained that any scholarly discussion on cultism without a spiritual touch has missed the link and the whole discussion will be termed a poverty of scholarship because cultism essentially isa spiritual matter. Ossai (2000) postulated that the higher education system in Nigeria is under siege, bombardment and almost ruined by secret cult. Thus, majority of the students, lecturers and their families live in perpetual fear. Under the cover of darkness, the gang torture, rape, kidnap, rob and maim anybody in the campus who dare cross their 
way. They cheat in examination openly and threaten lecturers. They are often with firearms, daggers, axes, and knives. In short, they are known as tin god and sacred cows of the campus.

In Brazil for instance, Paulo (1994) stressed that gangs were multiplying at a frightening rates. They attack rival gangs, people of another race and the poor migrant workers. According to the source, cultists robbed people on the beach, fought among themselves and turned a major avenue in Rio de Janerio into a war zone.

\section{The Prevalent Patterns of Poverty and Cultism in Our Contemporary Society}

Marshal (1998) defines poverty as the state in which resources, usually material but sometimes cultural are lacking and could be delineated into two broad categories of "absolute and relative" terms. Absolute poverty refers to "a state in which individuals lack the resources necessary for subsistence". The relative term refers to the individual's or groups' lack of resources when compared with that of other members of the society (Agbiokoro 2010).

Furthermore, campus cults have contributed a major threat to academic programmes in our higher institutions. These cults are often saddled with different interests and conflicting ideas. There are some groups that are interested in maintaining the supremacy of the 'Capone' and still there are others that are bent on undermining his power and such situations result in shooting and killing in the campus. The Capone's power is often checked by the elders. If the Capone abuses his power, there is bound to be revolt by some of his officers and such things happen in campuses where there might be coup against the Capone or mutiny in the rank and file of the soldiers.

The Capone survives his reign by using divide and rule tactics, where he uses one principle officer against another, and this can cause problem in the school. The Capone has different officers manned by capable hands for the smooth running of his affairs. His powers are composite and are lodged in different offices; it is entirely difficult for the Capone to collect the annual dues from members. A Capone has the right to tax members and get tribute from them. He has corresponding obligation to dispense justice to them to ensure their protection from rival cult group. Supernatural control of events in the bedrock of cultism and this ritualistic attitude has always been associated with everything cultic.

The Mau-mau cult of east and central Africa is one of the oldest local cults in Africa. Their initiation is like every other cult, but with some interesting differences like every other cult. Oaths taking by Mau-mau involves removal of shoes and shorts which is followed by the administrations of oaths of unity called "NdenwaIhatu". They are thoroughly tested to prove their abilities to absorb pain. This is followed by the passage of an Arch built with banana stems by intending initiates. The chief priest 
of this cult often holds the head of a goat in his hands and as he circles the ground the heads of intending initiates are required to be facing the ground. He normally circles the different heads of this initiates seven times after which he gives the new members the same goat to have a bite. After this an oath is given as follows:

I speak the truth and now before God, and this group, the movement of unity, the unity which is put to test the unity which is mocked with the name, mau-mau. That I shall go forward to fight for the land, and if I fail to do this, may this oath kill me, may this seven kill me and may this meat kill me. After this, the chief priest anoints the head of the new members with the blood saying that this is done to remind them of the fight ahead. After these, tiny marks of the mau-mau cults are scratched on the left wrist of members. The drops of blood from the wrist would drop into the meal which is later eaten. The chief priest thus chants "the act of eating in this meat, with the blood of each one of you shows that you are now united to one another and with us".

The oath gives cult members powers and strength and they have the belief of superiority above other non-cultists. The negative effect is that the cultists often regard their previous life as empty and the new form of life as fulfilling and as such the next thing is to trivialize their education. The invitation ceremony gives them a feeling of being born again and opportunity for dangerous adventures.

The zangbeto cult in Badagry Lagos is another cult that perform social and spiritual roles. They help to maintain law and order, and in keeping the community clean. By using its symbol of banana leaves in areas it does not want refuse dumps, indigenes automatically stop littering the area. The activities of these cults have made it possible for Badagry to be relatively crime free at that period. The head of this cult is called zanagan. He is the spiritual head. Secret cults in African societies are valuable as instrument of social control. There are other types like Ogboni, Oro, Egungun, Ekpe-Okpinon, Kamalu, Nfana, Eno-Orugbo, Oje, Gbara-jiko, Agemo, Awo-Opa, Igbe, Oghere-Uke and Ekpo.

The evil among cult groups can be seen in the atrocities they perpetuate in the campuses. Every cult group, be it local, foreign or in campuses is simply cultic and should be jettisoned from our socio-academic vicinity. Groups preferred secret rituals, nocturnal meetings, horrifying and dreadful practises. These cults are often known for organising and using individuals for revolutionary purposes, violent, social upheavals and subversion conspiracies against constituted authorities and violation of the integrity of man (mental and physical tortures). They exert blind obedience from members and are geared towards their selfishends against the norms of academic environment and the normal life of a civilized society. 
Campus cults differ in names but their activities are similar. An overview of the origin of some of these cult groups prevalent in the society are briefly outlined below:

National Association of Seadogs (Pirate Confraternity): The association was founded in the University of Ibadan in 1956. They have equally deviated and the outcome is unpalatable for the non-initiates called "Jew men". The flag of skull and cross bones are the authoritative symbol of this group. The term "Jolly Barger" was used first in 1700, though "Barger" is used today for Vikings members. The "black" background is the true representative, but "red" is often used even these days, especially when pirates intend to give no quarter. Their colours are "white and red". They have particular greeting form. The pirate confraternity is the oldest campus cult in our Universities. It is an offshoot of the pirates of England.

The Confraternity (Mafia Confraternity): This was founded in the University of Ife in 1972. Their colour is green, and their symbol is a casket with two staff aligned to it.

National Association of Air Lords (Five Confraternity): This was founded in the University of Ibadan. Their colour is "blue" with a carved wooden sculpture as their symbol.

National Association of Adventurers (The Vikings confraternity): This was founded in the University of Port Harcourt in 1982. Their colours are "black and red". The Vikings are seafarers. The first Viking raid was in the year A.D 787 when they used slim ships each with a single squad sail and long oars to raid the south coast of England. They used various types of musical instruments like battle axe, edge sword to butcher their victims. Viking is a Scandinavia cult.

Neo Black Movement (Black Axe Confraternity): This was formed in the University of Benin in 1984. This cult was founded as a result of the need to have pure black African group that is original and African. They believe in equality and individual freedom. They often display a great loyalty to one another, and it is often run in typical African way of doing things. Along the line they derailed like the foreign established ones, they started engaging in the fight for supremacy and these fights started to bring chaos in schools. They are fetish - oriented and believe in crude way of doing things that are un-African.

Other groups are the Black Beret (B.B), Trojan Horse, Temple of Eden, KKK, Osiris etc. All their activities are virtually shredded in oath-bond secrecy. Each of these cults have specific name with which they operate in the bush. They are called bush names. Examples of these bush names are; Obalende, Utake, Koko, etc. only initiates call their fellow members these names, and it equally functions to disguise the person's original names, and these bush names acts as deep covers. 


\section{Challenges Posed by Poverty and Cultism in the Nigerian Society}

Generally, the effects of poverty has differing effects on the Nigerian society, one of those effects is poor infrastructure which the government seemed to have neglected. Also, the manner of administration has been very poor and as such the basic needs of the citizen which the government should provide are not available. The incessant increase the prices of petroleum products have led to high cost of transportation, food and essential services. High prices of petroleum products means that the ordinary artisans, welders, vehicle battery chargers, barbers, spray-painters, etc. by the roadside that are self-employed and rely on electricity power have to pay heavily to do their businesses. This is because electricity power supply in the country is at its lowest level in recent years and those who do business with electricity power settle for the use of portable electricity power generator, which requires petroleum products to operate.

We are to note that while cost of living is rising, wages and salaries remain the same as low as less than N50,000.00 as average salaries per month paid to public servants at both the state and the federal levels. Sometimes industrial action is seen as solution to poor and irregular payment of salaries. Experience has shown that those who served the government in the public service never get their gratuity and until two years, and sometimes more after they are retired from public service. It was the fear of the above and worsening poverty situation in the country that made the former Nigeria Labour Congress (NLC) secretary, General John Odah to argue that "the impact of the forceful discharge of 33,000 federal public servants on family welfare will be predictably negative while it worsens the poverty profile of the country, which is already alarming by government admission" (IRINnews online 2001).

Nevertheless, there are consequences of being a cult member and these are contamination of deadly diseases through blood oath. During initiation, old members and new initiates normally take bloody oath from the mixture of blood of new initiates. This can certainly spread HIV/AIDS, Hepatitis B and other deadly diseases. Killing and destruction is another adverse effect of cultism. One can be a victim of intra or inter-cult clash. A member is prone to heinous crimes, violence and the future career if the cultists are expelled from school.

\section{Implications of Poverty and Cultism on Nigerian Students}

The effects of poverty in the lives of Nigerian students include: lack and deprivation in the basic necessities of life which education is one of these necessities. Owing to joblessness, the parents of these Nigerian students might find it difficult to fund the education of their children. Some of these students in order to find a way out may use their time for lectures to do other menial jobs to augument whatever that is given to them by their parents. Others without conscience and the fear of God may

Copyright (C) IAARR, 2015: www.afrrevjo.net

Indexed African Journals Online: www.ajol.info 
engage themselves in prostitution, robbery, cultism and other social vices. This has an adverse effect on the educational sector.

Campus cults have constituted a major threat to academic programmes in our Universities and other institutions of higher learning. These cults encourage moral ruin, murder, terrorism, sexual harassment, rape, armed robbery, prostitution among others in the campuses which are supposed to be centres for knowledge and skills acquisition. On the contrary, the cultists have turned some campuses into the devil's nest or something entirely different. Instead of justice, there is survival of the fittest, instead of peace and love we find tales of horror and brutality. There are also intimidations, torture and murders. Morality seems to have gone to zero degree, and academic pursuit which is supposed to be of primary importance has been relegated to secondary priority.

Obviously, some of the implications of cultism on the learning process cannot be exhausted as both intra and inter-cult clashes negatively affect the students' academic performance in a high proportion. It sometimes leads to incarceration, rustication of both innocent students and student cult members (Opaluwah 2009), or they may spend more than the required number of years necessary for graduation (Ogidefa 2008).

Cult activities may disrupt the academic calendar of the national institutions of learning (Ogidefa 2008). The peace on campus is adversely affected whenever there is cult invasion, this may result in suspension of academic activities for sometimes and expulsion of cult members from school when they have been identified (Opaluwah 2009). This singular activity can affect the years of graduation of students and may discourage other students towards continuing their study in the institution concerned. Mgbekem (2004) also observed that "many lives and properties have been destroyed through cult violence". Young undergraduates who are supposed to be leaders in future have fallen victims of trigger happy cultists (Jamiu 2008).

Another implication of cultism as noted by Ogidefa (2008) is that, before and during examinations, students organize vigils and pray for a successful end of examination and or semester. Yet, they always sleep with one eye closed because of the frequent cult disturbances and insecurity. Some parents prefer off campus accommodation for their children in tertiary institutions for fear of being victims of campus cultists' rampage (Mgbekem 2004).

Some members of cult groups receive physical injuries during their initiation ceremonies .The implication is that this bodily harm may result in untimely death especially for those who cannot endure the pains. Closely related to this is the fact that some of them suffer health hazards because of intake of harmful drugs such as marijuana and cocaine among others. In addition, other implications of cultism among 
students include: mismanagement of the money they would have used to pay for their school fees, buy books, etc, rather they use such money to give financial assistance to their cult groups without placing value on their own lives. Also, they subvert the genuine students' unionism and destabilize the school programme without recourse to their prospects in academics. Cult groups often subvert the genuine students' unionism and destabilize the school programmes and administrations without recourse to their prospects in academics because they do not condone their nefarious activities (Ogidefa 2008).

\section{Measures for Curbing Poverty and Cultism in the Society among Nigerian Students}

For poverty and cultism to be curbed every hand must be on the deck, the government, and individuals should help to find the waysout of the trends. Government has initiated some programmes to overcome poverty. These programmes include: Directorate of Food Roads and Rural Infrastructure (DFRRI), Better Life Programme (BLP), National Directorate of Employment (NDE), Peoples Bank of Nigeria (PBN), National Economic Empowerment Development Strategy (NEEDS). Their aims are to ameliorate the sufferings of the people by providing them employment opportunities and access credit facilities to enable them establish their own businesses.

Faced with the challenges of poverty in the country, the government went further to initiate more policies. These policies are initiated at home and received support from abroad including the World Bank. For instance, in a bid to reduce poverty, the World Bank has assisted the country in various projects. Since 1961 Nigeria joined the World Bank, the country has received assistance on more than 120 projects worth more than $\$ 1.87$ Billion (Word Bank, 2006). These projects include:

1. The Micro-Small and Medium Enterprises (MSMEs): This is a US \$ 32 million project which aims at increasing the performance and employment levels of MSMEs in selected non-oil industry sub-sectors in three targeted states of the country. The purpose of this scheme is to diversify Nigerian economy from relying solely on crude oil as her source of foreign exchange earner.

2. The Second Fadama Development Project: This is a US $\$ 100$ million project with the objective for sustainable increase in incomes of Fadama users. Those who depend directly or indirectly on Fadama resources (farmers, pastoralists, fishers, hunters, gatherers and service providers). The purpose of this project is to provide meaningful means of livelihood to nomadic cattle rearers in the Northern part, hunters and fishermen in the southern part of Nigeria.

3. Local Empowerment and Environmental Management Project (LEEMP): This is US $\$ 70$ million operation which seeks to strengthen the institutional 
framework at the three levels of governments (Federal, State and Local government) to support an environmentally sustainable, socially inclusive development, and to produce state beneficiaries' participation in the planning, co-financing and implementing of multisectoral micro-projects.

In order to overcome the problems of poverty in the country, the war against corruption should be intensified. Therefore various anti-corruption agenciesIndependent Corrupt Practices Commission (ICPC) and Economic and Financial Crime Commission (EFCC), should be allowed to operate freely and devoid of executive interference. In addition, government policies should reflect the needs and aspirations of the people at all levels and at all times. Other ways of curbing poverty are that the government is to put in place what Igbuzor (2005) called "promotion of pro-poor policies"; pro-poor policies that focused on the welfare of the poor. Policies that would favour job creation like the establishment of Small and Medium Scale Enterprises (SMEs) should therefore be the focus of government. This is because SMEs have been found to be not just job creators but creators of wealth in the society (Ogodo, 2005).

For Nigeria's sorry socio-economic situation to improve, the nation needs honest and God-fearing men to be in charge of her affairs. For development to take place in any society there must be serious transformation in the quality of governance. Good governance which will create reliability and co-operation for all parties involved. Adequate funding will improve the nation's economy when the objectives of these policies are achieved. If possible, all funds ear- marked for any programme should be made completely available before the commencement of the project. Concerted efforts should be made by all stakeholders to guarantee political stability and continuity of programmes and policies.

Furthermore, there should be a fundamental infrastructural development scheme. Initiation of team of supervisors whose programme of activities are in line with the yearnings and aspirations of the target population should adopt punitive measures and show their willingness and readiness to punish those who sabotage their efforts. Nigerian leaders need to take a cue from the Western World on measures taken to reduce their peoples' suffering. Public works, textile industries and the development of agriculture among others have the capacity to provide jobs for these teaming youths. Also affordable healthcare and counselling will go a long way to alleviate the peoples sufferings thereby reducing the risk associated with the patronage of uncertified chemists.

Finally, the educational system is in a state of collapse due to poor funding. Government should then invest in public schools. The proliferation of private schools in Nigeria is a consequence of improver funding of public schools. Proper funding of public schools will help raise the standard of education besides education is central to 
the development of any nation. The high level of illiteracy in the country is enough for government to ensure that every citizen get the best education. It is sad to note that parents who cannot afford to put their children in private schools send their wards to the decaying public schools thereby reducing their chances of getting better education. The children of the poor must not be left to the mercy of poorly funded public schools.

On cultism, it can be curbed using cultism management techniques. In Nigeria, the government, corporate bodies, religious organisation should make frantic efforts to see that cultism is brought under-control through proper management. Osaigbovo (2000) identified the following cultism management techniques. These techniques are coercion, persuasion, public awareness campaign, public renunciation and school disciplinary measures.

Coercion is a common knowledge that cultism operate violently. Probably this was why Ede (1995) and Ige (2000) advocated that suspected cultists arrested should be tried and if found guilty should be jailed or hanged depending upon the magnitude of the offence. On the other hand, Osemeikhan (1998) and Sowore (1998) maintained that the use of force to curb cult activities may not yield any positive result since members of these secret cults are already used to violence. As far as Onah (1999) is concerned, cultists should be handled with care and through the use of force.

Persuasion is among the techniques that may be used in stamping out cultism. No wonder Oladujoye (2001) asserted that through persuasion, students were seriously appealed to about the evils of cultism and they were encouraged to renounce membership. However, Alemika (2000) stated that the only way in which cultism can be eradicated in tertiary institutions is by involving spiritual leaders to organize noncongregational service and counselling in schools.

Public awareness is another vital means through which cultism may be effectively minimized if not totally eradicated. To this effect, Osaigbovo (2000) stressed that through seminars workshops symposium, posters, handbills and public lectures, cultism maybe effectively combated. Bamidele (1994) and Idogun (1999) advocated the use of public enlightenment, public lectures and seminars as ways of combating cultism.

Public renunciation is a fellow up for persuasion. The success recorded in persuasion may lead to public renunciation of cultism by students. Oladunjoye (2001) supported this view thus" in various institutions of higher learning a good number of repentant students who openly renounced their membership of cultism surrender their instruments of operation"

The last but not the least technique is school disciplinary measures. It may be interesting to note that the task of identifying cultists by the authorities of higher institutions is not an easy one. Membership of secret cults may not be restricted to 
students alone, but highly placed members of higher institutions may equally be members. Therefore, a situation where a student cultist is brought before the school authority who is a cultist, justice may not prevail. Probably, this was why Effiong (2000) stated that the management of cultism must not be allowed to rest on the shoulders of the school administrators alone because it may not yield fruitful results. Withdrawal, expulsion and rustication have been the major strategies or weapons of school administrators right from time to time but the incidence of cultism keeps rising. Omar (2000) stated that expulsion, withdrawal and rustication will continue to be effected in nearly all the institutions of higher learning as long as cult members are detected and arraigned before disciplinary panel.

Curbing cultism can be achieved through the government, parents, churches, and the students' positive resolutions towards actualising their goals in their academics. Government should show interest in education and fund the institutions of higher learning in the country more. It is due to poverty that some female students prostitute in order to meet the financial demands of their schooling. The government should resuscitate facilities like scholarship, bursaries, so that these young people concentrate in their studies and have no opportunity to indulge in cultism.

Parents also have a very big part to play in inculcating morality in their children because cultist exists in even in primary and secondary schools. Successful parenting requires courage and parents should be close to their children. The churches also have their role to play. They should organize programmes to sensitize children about the evils of cultism. They should also preach about cultism from the pulpit.

The students too should note that it is hard work before pleasure and face their studies with all concentration, pre-occupy themselves with religious activities or programmes such as Christian association on campus where they can grow spiritually, so that they will not succumb to peer pressures. The school authorities should desist from various abuses through various inconsistent policies which often lead students to think of protecting their interest with whatever means at their disposal.

The enactment of degree 47 of 1989 that pronounced a number of jail term for any cultist found guilty should be enforced (Fasami 2008). Also, the Federal Republic of Nigeria under Chief Olusegun Obasanjo in 2000 issued a three month ultimatum to all Vice-chancellors to eradicate cultism from the campuses. Some higher institution also set up anti-cult groups consisting of the student body itself and security agents to monitor and check the activities of cultists on campus (Adewale, 2000). Effiong (2005), posited that it is very necessary for the committee of Vice-chancellors of the Nigerian Universities, Rectors of Polytechnics and Provosts of Colleges of education 
to adopt a uniform approach to combating the menace of cultism in our higher institutions.

\section{Conclusion}

In conclusion, this paper examined the origin, causes, implications, prevalent patterns and measures to curb poverty and cultism in Nigerian contemporary society. Government and individual efforts, programmes and policies were $\mathrm{x}$-rayed to find out their strengths and weaknesses and suggestions were made as a way forward. The objectives of poverty alleviation agencies and programmes would be achieved if the successive government do not discard their predecessors' programmes, rather add their own suggestion (still under the same umbrella) and all programmes would run concurrently to ensure that all target audiences are reached. In terms of structure, the agencies should house all the poverty alleviation programmes. Units/sections should be created to monitor each of the programmes according to their peculiarities. By so doing, programmes will be able to stand on the premise of the day. Even when a programme is having conflicting objectives, it can easily be harmonised since they are all premised on the same foundation. For clear administrative purpose, there should be self-accounting and responsible to the presidency. Such agency should be included in the budget and should align with international agencies of relevant purposes. This can help to secure the existence of an agency and ensure continuity of future programmes. Also, there should be creation of job opportunities especially for our graduates, good governance, and provision of fundamental infrastructures for development and proper funding of the education sector for poverty alleviation.

Since cultism exists in higher institutions in Nigeria, the use of coercion, persuasion, public awareness campaign, public renunciation and school disciplinary measure could serve as weapons for the eradication of cultism in our society. On the part of parents, university authorities, religious groups, government and nongovernment organisations and agencies, all hands must be on deck to combat this ugly trend that has gained ground in our higher institutions. 
AFRREV, VOL. 9(2), S/NO 37, APRIL, 2015

\section{References}

Aboribo, R. I. (1999). Secret cults in Nigerian universities, political, Economics and Spiritual Dimension. A Paper Presented at the Maiden National Annual Conference of the National Association of the Advancement of Knowledge (NAFAIL) Delta State University, Abraka, Delta State, Nigeria.

Adejoro, B. (1995). Lagos SAR students interview. Yaba College of Technology.

Adewale (2000). In Educational 539340, Friday, 22nd June 2014. 6.05 pm.

Alemike, E. E. O. (2000). Management of Students Unions and Anti-cult Union and Anti-cult mobilization in Nigeria Tertiary Academic Institutions. A Paper Presented at the workshop on Security Issues in the Eradication of Cultism in Tertiary Institutions, Abuja.

Akintola, J. O. \& Yusuf, J. M. (2001). Socio-economic analysis of poverty levels among rural dwellers in Kwara State. Nigeria International Journal of Environment and Development, Vol 5, No 2.

Bamidele, O. (1994). The campus cult menace. National concord, concord press limited.

Ede, S.N. (1995). University management in Nigeria: Key issues. Jos: Source Publishers.

Effiong, J. (2000). 50,000 students, teachers injured by cultism. The Punch, Monday May 7, vol 17, No 17902.

Ekoko, E. A. (1999) Nigeria Universities as War front Diagnosis and prognosis. A Paper Presented at the 1999 Annual Lecture of the University of Ibadan Alumni Association, Asaba.

Idogun, M. (1999). Eliminating cultism. Vanguard, Thursday, September 1999.

Ige, B. (2000). Death penalty for students cultism. The Punch, Wednesday June Vol.17, No 7904.

Igbuzor, O (2005). Alternative Poverty Eradication Strategy for Nigeria. In John Moru (ed). Another Nigeria is possible. Abuja: National Social Forum Publication.

Marshal A. (1998). Principle of economics. 8th Edition London: Macmillan.

Obadan, M. I. (1996). Poverty in Nigeria: Characteristics of alleviation strategies and programmes. NCEMA Policy Analysis Series Vol. 2: No 2.

Ogodo, D.W. (2005). The Role of Capital Market in SME financing. The Nigerian stock market annual (NSMA). Lagos: CITC, Plc. Group. 
Oladunjoye, P. (2001). Staff and Students Perception of Method of Management of Cultism in Higher Institutions in Edo and Delta States. An Unpublished Ph.D. Thesis. Delta State University, Abraka Delta State.

Onah, R.C. (1999). Youths Anti Secret Cults in Institutions in the 21st century. An Unpublished Paper Presented at the maiden National Conference of the National Association for the Advancement of Knowledge (NAFAK) Held at the Delta State University, Abraka.

Osaigbovo J. A. (2000). Cultism and Administration of Higher Education in Nigeria Programmes. Seminar for Ph.D. Delta State University, Abraka, Nigeria.

Osemeikhian, T. A. (1998). Factor of Crises Panacea for Campus Cultism. The Punch. 16th October.

Ossai, A.G. (2001). Cultism and the Management of Higher Education. A Seminar Paper Presented at the Faculty of Education, Delta State University, Abraka.

Paulo, B. (1994). The gang. Chicago: Chicago Press University.

Sowore, O. (1994). I was almost killed. Tell, 2nd March.

Thompson, S. A. (1998). Introduction to cultism. London: Routledge and Regan Paul Ltd.

The Oxford Concise Dictionary: University Press PLC Ibadan.

World Bank (2006). Report on Nigeria. Retrieved on April 3rd. 